\title{
Centesimal composition and physical-chemistry analysis of the edible mushroom Lentinus strigosus occurring in the Brazilian Amazon
}

\author{
CECI SALES-CAMPOS ${ }^{1}$, LIDIA M. ARAUJO ${ }^{2}$, MARLI T.A. MINHONI ${ }^{3}$ and MEIRE C.N. ANDRADE ${ }^{4}$ \\ ${ }^{1}$ Instituto Nacional de Pesquisas da Amazônia, Coordenação de Tecnologia e Inovação, \\ Caixa Postal 478, 69060-001 Manaus, AM, Brasil \\ ${ }^{2}$ Universidade Federal do Amazonas, Departamento de Química, Mini-Campus, Bloco M, \\ Av. Gal. Rodrigo Octávio Jordão Ramos, 3000, Bairro Coroado, 69077-000 Manaus, AM, Brasil \\ ${ }^{3}$ Universidade Estadual Paulista, Faculdade de Ciências Agronômicas, Departamento de Produção Vegetal, Módulo de \\ Cogumelos, Rua José Barbosa de Barros, 1780, Fazenda Lageado, Caixa Postal 237, 18610-307 Botucatu, SP, Brasil \\ ${ }^{4}$ Universidade do Sagrado Coração, Centro de Ciências Exatas e Sociais Aplicadas, \\ Rua Irmã Arminda, 10-50, Jardim Brasil, 17011-160, Bauru, SP, Brasil
}

Manuscript received on April 11, 2012; accepted for publication on April 3, 2013

\begin{abstract}
The centesimal composition and the physical and chemical analyses of Lentinus strigosus, an edible mushroom occurring in the Brazilian Amazon and produced in alternative substrates based on wood and agroindustrial residues, were evaluated. For this purpose, the $\mathrm{C}, \mathrm{N}, \mathrm{pH}$, soluble solids, water activity, protein, lipids, total fiber, ash, carbohydrate, and energy levels were determined. The substrates were formulated from Simarouba amara Aubl. ("marupá"), Ochroma piramidale Cav. Ex. Lam. ("pau-debalsa") and Anacardium giganteum ("cajuí") sawdust and Bactris gasipaes Kunth ("pupunheira") stipe and Saccharum officinarum (sugar cane bagasse). The results indicated that the nutritional composition of L. strigosus varied with the substrate of cultivation; the protein levels found in mushrooms grown in the different substrates $(18-21.5 \%)$ varied with the substrate and was considered high; the soluble solids present in the mushrooms could have a relation with complex B hydrosoluble vitamins. L. strigosus could be considered as important food owing to its nutritional characteristics such as high protein content, metabolizable carbohydrates and fibers, and low lipids and calories content.
\end{abstract}

Key words: edible mushroom, nutritional value, minerals, protein, fibers.

\section{INTRODUCTION}

Several publications have highlighted the mushroom as food with high protein value, as a source of food fiber and vitamins as well as low lipids content (Chang and Miles 1989, Manzi et al. 1999, Sapata 2005). However, it should be noted that there is great variability in the nutritional composition of

Correspondence to: Meire Cristina Nogueira de Andrade

E-mail:mcnandrade@hotmail.com mushrooms among the same species and between different species (Sturion and Oetterer 1995, Wang et al. 2001, Silva et al. 2002, Furlani 2004, Sapata 2005, Das and Mukherjee 2007). The variations could result from different factors such as: the mushroom species, strains, type of substrate used, maturation degree of the mushroom, type of storage, parts of the mushroom examined, and the conservation process (Andrade et al. 2008, Furlani 2004, Crisan and Sands 1978). 
When studying the viability of mushroom cultivation in alternative substrates, it is important to know the nutritional composition of the species grown in relation to such substrates. Many of the basidiomycete fungi that decompose wood and other lignocellulosic material are also edible fungi, like Lentinus strigosus (Schwein.) Fr., which can be used in the process of exploiting the residues owing to the special metabolic activity.

Many species of the genus Lentinus are considered as a primary decomposers of wood and other plant residues, and are known for their ability to be grown in various residues. Mushrooms of this genre, such as L. Strigosus, have been studied particularly regarding their cultivation in different residues (Lechner and Albertó 2007, Kadiri and Arzai 2004), although they have been rarely cultivated in the world. Nevertheless, there are no records in the scientific literature about the nutritional composition of $L$. strigosus.

Thus, the present study aims to evaluating the centesimal composition and the physical and chemical analyses of an L. strigosus strain occurring in the Brazilian Amazon, produced in substrates based on wood and agroindustrial residues.

\section{MATERIALS AND METHODS}

The study was carried out at the Coordenação de Tecnologia e Inovação (CTI) of the Instituto Nacional de Pesquisas da Amazônia (National Institute of Researches in Amazon - INPA), at the Analysis Laboratory of Soil and Plants of the same Institute, at the Fishing Laboratory and at the Analytical Center of the Universidade Federal do Amazonas.

The sawdust used in the preparation of the substrate were as follows: Simarouba amara Aubl. ("marupá"), Ochroma piramidale Cav. Ex. Lam. ("pau-de-balsa"), and Anacardium giganteum ("cajuí"). The agroindustrial residues were: Saccharum officinarum (sugar cane) bagass and Bactris gasipaes Kunth ("pupunheira").
The choice of wood residues generation was based on their generation by the local timber industry. The agroindustrial residues were acquired from sugar cane juice micro industries and pupunheira stipe from the disposal of the palm production. The collection, drying, and preparation of the material were carried out at the CTI/INPA.

All the samples were dehydrated in a solar drier of the CTI/INPA and packaged separately in plastic tanks of 100 liters until the preparation of the substrate for the test with the fungus, according to Sales-Campos (2008).

After the cultivation, the mushroom samples were divided according to the origin of collection (substrate), and coded according to the residue in which the substrates were formulated: SIAMPCOG ("marupá"); SIAPB-COG ("pau-debalsa"); SIACJ-COG ("cajuí"); SIAPP-COG ("pupunheira"); and SIACN-COG (sugar cane).

The mushrooms of each type of substrate were homogenized and dried in stove with circulating air at $55^{\circ} \mathrm{C}$. They were then crushed in Willey knife mill and packed in sealed bottles and kept under refrigeration for further evaluation of the centesimal composition and the physical and chemical analyses.

pH DETERMINATION

The $\mathrm{pH}$ determination of the mushrooms was done using a potentiometer, previously calibrated with buffer 7 and 4, following the methodology recommended by the AOAC (1997). A total of three repetitions per sample ( $3 \mathrm{~g})$ were carried out. The material was diluted in distilled water followed by reading in a Tecnal digital potentiometer.

\section{DETERMINATION OF ORGANIC CARBON CONTENT}

The organic carbon was determined by the Walkley Black method, according to Mendonça and Matos (2005). For this purpose, $0.01 \mathrm{~g}$ of the sample was used, instead of $0.5 \mathrm{~g}$, owing to the large amount of carbon present in the sample. The amount of carbon 
was determined by its oxidation in humid way (dichromate + sulphuric acid) and the maximization of oxidation was obtained by external heating. The result was obtained by two complementary formulas: $\mathrm{A}=[(\mathrm{Vba}-\mathrm{Vam})(\mathrm{Vbn}-\mathrm{Vba}) / \mathrm{Vbn}]+(\mathrm{Vba}-$ Vam), where:

$\mathrm{Vba}=$ volume spent in the titration of the white control with heating;

$\mathrm{Vbn}=$ volume spent in the titration of the white control without heating;

Vam $=$ volume spent in the titration of the sample

$\% \mathrm{C}=\frac{(\mathrm{A}) \text { (molarity of ferrous sulphate) (3) (100) }}{\text { Mass of the sample (mg) }}$

$3=$ result of the ratio between the number of moles of dichromate that react with iron, multiplied by the number of moles of dichromate that react with carbon, multiplied by the atomic mass of carbon (12);

$100=$ unit of percentage.

\section{DETERMINATION OF TOTAL NitROGEN AND PROTEIN}

The Kjeldahl was employed for the analysis of total nitrogen, which involved three steps: digestion, distillation, and titration (Malavolta et al. 1989, AOAC 1997), by using the following formula:

Nitrogen\%: (V x 0.0014 / M) x 100

where,

$\mathrm{V}=$ Volume of $\mathrm{H}_{2} \mathrm{SO}_{4}$ spent in titration, $\mathrm{mL}$

$\mathrm{M}=$ Mass of the sample $(\mathrm{g})$

For the conversion of nitrogen into protein the following formula was used, considering that $100 \mathrm{~g}$ of protein contains an average of $16 \%$ of nitrogen:

Protein $\%=\mathrm{N} \% \times 4.38$ for the mushrooms

\section{WATER ACTIVITY}

The water activity (Aa) in the mushrooms was determined using a Pawkit water activity analyzer with a technical calibration and adjustment certificate (Braseq 2005).
The water activity is represented by the formula Aa = P / P0 (Maltini et al. 1993, Eira 2003).

Refractometry was used for measuring the refraction index of the sugar solution containing the mushrooms. The samples were homogenized and diluted in a small amount of distilled water, and large particles were discarded. One to two drops were transferred to the prism of the refractometer and read in the scales in Brix degree (Carvalho et al. 2002).

\section{DETERMINATION OF HUMIDITY AND DRY MASS CONTENT}

The moisture content of the samples cited was determined by the dissection method in stove at $105^{\circ} \mathrm{C}$ until constant mass was achieved. One gram of each grinded sample (three repetitions per sample) was weighed with a precision of $0.01 \mathrm{mg}$ in analytical balance in crucibles; the material was dried in stove at $105^{\circ} \mathrm{C}$ for four hours. The crucibles were then transferred to a dissector with silica and left for cooling until environment temperature. Subsequently, they were weighed and the operation was repeated until constant mass. Humidity was expressed by the following formula:

$\mathrm{U} \%=\frac{\mathrm{M} 1-\mathrm{M} 2}{\mathrm{M} 1} \times 100$

$\mathrm{U}=$ Percentage of humidity

M1 = initial mass of the sample

M2 = final mass of the sample

Dry mass was calculated as MS\% $=100-\mathrm{U}$

\section{LIPIDS}

The dissected samples were submitted for extraction with mixtures of cold solvents by the Bligh and Dyer method in triplicates. The solvents used in this technique were chloroform, methanol, and water. The sample was mixed with the solvents, and the chloroform stage contained the lipids. This stage was separated after the evaporation of the chloroform. The amount of lipids was obtained by weighing and the results were expressed in grams per $100 \mathrm{~g}$ of the sample (Carvalho et al. 2002). 
TOTAL FIBER

The total fiber content was determined by the Weende method (AOAC 1997). The fat was removed, and the samples were weighed around $2 \mathrm{~g}$ in triplicates and submitted to acid digestion. All samples were adapted to a Tecnal TE 146/8-50 and TE 146/5-50 fibers determinator system. In a second step, the samples were submitted to alkaline digestion, in a $1.25 \% \mathrm{NaOH}$ solution. The results were expressed in grams of total fiber by $100 \mathrm{~g}$ of samples.

\section{ASH OR FIXED Mineral RESIDUE}

The ash content of a sample corresponds to the fixed mineral residue obtained after the decomposition of all the organic components. The analysis consisted in dissecting the samples, weighing around $1 \mathrm{~g}$ in triplicate, carbonization, and calcination in furnace, at $550^{\circ} \mathrm{C}$. The results were expressed in \% (AOAC 1997).

\section{TOTAL CARBOHYDRATES}

The total carbohydrates were calculated by difference (100 - total grams of humidity, protein, lipids, and ash), including fiber fraction. The result was given in percentage terms (LATINFOODS 2002, NEPA 2006).

\section{AVAilable CARBOHYDRATES}

These are metabolizable carbohydrates, which were calculated by difference and by excluding fiber fraction (100 - total grams of humidity, protein, lipids, ash, and fiber) (LATINFOODS 2002, NEPA 2006).

\section{ENERGY}

The total metabolizable energy is expressed in kilocalories (kcal / 100g), which was calculated by considering Atwater's conversion factors: $(4 \mathrm{x} \mathrm{g}$ protein $)+(4 \times \mathrm{g}$ carbohydrates [total carbohydrates - food fiber] $)+(9 \mathrm{x}$ g total lipids), as recommended by LATINFOODS (2002) and NEPA (2006).

\section{RESULTS AND DISCUSSION}

It was observed that the carbon contents of the mushroom presented close values even when grown in different residues $(36.72-37.86 \%)$ (Table I). The mushroom grown in crushed sugarcane had $3.44 \%$ of $\mathrm{N}$, while the production in the residue formulated from the residue of marupá had lower $\mathrm{N}$ content $(2.81 \%)$. The results agree with the $\mathrm{N}$ values present in most of the mushrooms (2.27$5.13 \%$ ), according to Chang and Miles (1989).

The soluble solids present in mushrooms were found to vary with the cultivation substrates (Table I). The values for SIAMP-COG, SIAPB-COG, SIAPPCOG, SIACN-COG, and SIACJ-COG were 1.82, 3.64, $3.64,3.89$, and $3.14 \%$, respectively, with the highest content present in the mushroom grown in substrates made from sugar cane. It is possible that soluble solids' contents are also related to the presence of water soluble vitamins of the complex $\mathrm{B}$, as mushrooms are sources of vitamins, especially those of complex B, ascorbic acid, and ergosterol, which transforms to vitamin D in the presence of ultraviolet light (Crisan and Sands 1978, Gunde-Cimerman 1999). However, analyses of the soluble solid contents regarding the content of the vitamins were not the objective of this study.

The $\mathrm{pH}$ values were found to be practically similar between mushrooms grown in the different substrates (5.39 - 5.73) (Table I), as well as the corresponding values to water activity $(\mathrm{Aa})$ that ranged from 0.57 to 0.61. This is important for their conservation as low water activity makes microbial proliferation in the processed (dried and powdered) mushroom impossible, since microbial deterioration rate decreases as water activity is close to 0.60 and there is no microbial growth below that value (Eira 2003).

For the assessment of the protein content, the $\mathrm{N}$ conversion factor to protein used was 4.38 which takes into account the deletion of non-protean $\mathrm{N}$ from the chitin of the cell wall of fungi (Miles and Chang 1997), instead of 6.25 which is typically used for most food, avoiding protean super estimation. 
TABLE I

Results of physical and chemical (soluble solids, pH, Aa), carbon (C), nitrogen (N) and $\mathrm{C}: \mathrm{N}$ ratio analyses of Lentinus strigosus mushroom grown in different substrates.

\begin{tabular}{|c|c|c|c|c|c|c|}
\hline \multirow{2}{*}{$\begin{array}{l}\text { L. strigosus grown in } \\
\text { different substrates }\end{array}$} & $\mathrm{C}$ & $\mathrm{N}$ & $\mathrm{C} ; \mathrm{N}$ & Soluble solids & $\mathrm{pH}$ & $\mathrm{Aa}$ \\
\hline & $(\%)$ & $(\%)$ & $(\%)$ & ${ }^{\circ}$ Brix & & \\
\hline \multirow{2}{*}{ SIAMP-COG } & $(0.14)$ & $(0.16)$ & $(0.83)$ & & & \\
\hline & 37.86 & 2.81 & 13.47 & 1.82 & 5.39 & 0.58 \\
\hline \multirow{2}{*}{ SIAPB-COG } & $(0.21)$ & $(0.06)$ & $(0.15)$ & & & \\
\hline & 37.26 & 3.16 & 11.79 & 3.64 & 5.73 & 0.60 \\
\hline \multirow{2}{*}{ SIAPP-COG } & $(0.12)$ & $(0.06)$ & $(0.19)$ & & & \\
\hline & 36.86 & 3.29 & 11.20 & 3.64 & 5.41 & 0.61 \\
\hline \multirow{2}{*}{ SIACN-COG } & $(0.05)$ & $(0.22)$ & $(0.72)$ & & & \\
\hline & 37.04 & 3.44 & 10.77 & 3.89 & 5.47 & 0.57 \\
\hline \multirow{2}{*}{ SIACJ-COG } & $(0.04)$ & $(0.03)$ & $(0.11)$ & & & \\
\hline & 36.72 & 2.83 & 12.98 & 3.14 & 5.51 & 0.60 \\
\hline
\end{tabular}

SIAMP-COG: Mushroom grown in the substrate with "marupá" sawdust; SIAPB-COG: with "pau de balsa" sawdust; SIAPPCOG: with grinded "pupunheira" stipe bagass; SIACN-COG: with crushed sugar cane; SIACJ-COG: with "cajuí" sawdust. Numbers in bold: average of three repetitions per analysis. Values between parentheses refer to standard deviation.

The protein levels found in mushrooms grown in the different substrates used in this study $(18-21.5 \%)$ (Table II) are within the range reported for Miles and Chang (1997), compiled from various authors, and show that Agaricus bisporus, Flamulina velutipes, Lentinus edodes, and Volvariella volvaceae contain $23.9,17.6,13.4$, and $21.2 \%$ of protein in dry basis, respectively. Andrade et al. (2008) found variations of $20-24.3 \%$ of protein for $L$. edodes. The author, however, used an $\mathrm{N}$ conversion factor of 6.25 for protein, thereby causing super estimation of protein for that mushroom, which would correspond to the range of $14-17 \%$ by applying the conversion factor of 4.38 .

The cultivation of $P$. tuber-regium was tested by Faside and Ekuere (1993) in banana leaf, corncob, cotton plant residue, and rice straw. The protein contents of the mushroom grown in the respective residues in dry basis were $16.8,15.4,15.1$, and $13 \%$. It was found that the protein content for the mushroom grown in banana straw was lower than the results presented for $L$. strigosus grown in wood and agroindustrial residues as well as that obtained in this research (Table II).

Silva et al. (2002) used three types of substrates for the cultivation of $P$. pulmonarius: residue made of cotton plant, sheets of citron grass, and a type of forage plant. The protein levels for the substrates were $10.64,7.87$, and $7.55 \%$, respectively.

In this study, the protein percentages of the mushroom grown in the corresponding substrates were $20.03,16.90$, and $26.82 \%$, which present a higher protein value for the mushroom grown in the substrate of lower protein value (the Panicum maximum forage). Thus, in both cases, the results indicated that the highest protein content obtained in the mushroom did not correspond to the highest protein content of the cultivation substrate; a similar result was obtained in the study of Yildz et al. (1998). The authors used different cereals' straw, and mainly sorghum as substrate with highest protein content (9\%). The mushroom with highest protein content, however, was found to be that mushroom grown in peanut straw, the substrate with half of the protean value of sorghum straw (4.75\%).

Several weeds were used isolated and mixed to rice straw for the cultivation of $P$. ostreatus originating in India (Das and Mukherjee 2007). The largest protein content was found to occur in the mushroom grown in Cassia sophera grass (10.85 mg. $\mathrm{g}^{-1}$ of mushroom in fresh basis), although it was not the substrate promoting highest productivity.

As for lipid contents found in the mushroom grown in the different residues, the results were 
TABLE II

Result of the centesimal composition of Lentinus strigosus in different substrates.

\begin{tabular}{|c|c|c|c|c|c|c|c|c|c|c|}
\hline \multirow[b]{2}{*}{$\begin{array}{c}\text { Mushroom } \\
\text { per Substrate }\end{array}$} & \multirow[b]{2}{*}{$\begin{array}{c}\text { Protein } \\
(\mathrm{N} x 4.38) \\
(\%)\end{array}$} & \multirow[b]{2}{*}{$\begin{array}{l}\text { Lipids } \\
(\%)\end{array}$} & \multirow[b]{2}{*}{$\begin{array}{l}\text { Total } \\
\text { Fiber } \\
(\%)\end{array}$} & \multirow[b]{2}{*}{$\begin{array}{l}\text { Ash } \\
(\%)\end{array}$} & \multicolumn{2}{|c|}{ Humidity } & \multirow[b]{2}{*}{$\begin{array}{l}\text { Dry mass } \\
(\mathrm{MS})(\%)\end{array}$} & \multirow[b]{2}{*}{$\begin{array}{c}\text { Total } \\
\text { Carbohydrate } \\
(\%)\end{array}$} & \multirow[b]{2}{*}{$\begin{array}{c}\text { Available } \\
\text { carbohydrate } \\
(\%)\end{array}$} & \multirow[b]{2}{*}{$\begin{array}{c}\text { Total } \\
\text { Metabolizable } \\
\text { Energy (\%) }\end{array}$} \\
\hline & & & & & $\begin{array}{c}\text { Fresh } \\
\text { mushroom } \\
(\%)\end{array}$ & $\begin{array}{l}\text { Dehydrated } \\
\text { mushroom } \\
(\%)\end{array}$ & & & & \\
\hline \multirow{2}{*}{ SIAMP-COG } & & $(0.05)$ & $(0.64)$ & $(0.38)$ & $(0.78)$ & $(0.17)$ & & & & \\
\hline & 18.00 & 2.43 & 16.00 & 5.57 & 82.19 & 11.74 & 88.26 & 62.69 & 47.43 & 281.87 \\
\hline \multirow{2}{*}{ SIAPB-COG } & & $(0.05)$ & $(0.30)$ & $(0.33)$ & $(2.80)$ & $(0.11)$ & & & & \\
\hline & 20.00 & 2.39 & 14.25 & 5.47 & 83.38 & 12.45 & 87.55 & 59.95 & 45.70 & 283.32 \\
\hline \multirow{2}{*}{ SIAPP-COG } & & $(0.08)$ & $(1.57)$ & $(0.17)$ & (1.63) & $(0.40)$ & & & & \\
\hline & 20.56 & 2.69 & 13.64 & 5.72 & 84.01 & 12.29 & 87.71 & 58.75 & 45.10 & 286.83 \\
\hline \multirow{2}{*}{ SIACN-COG } & & $(0.03)$ & $(2.87)$ & $(0.62)$ & $(1.55)$ & $(0.32)$ & & & & \\
\hline & 21.50 & 2.45 & 16.17 & 5.01 & 84.88 & 12.53 & 87.47 & $\mathbf{5 8 . 5 2}$ & 42.34 & 277.40 \\
\hline \multirow{2}{*}{ SIACJ-COG } & & $(0.12)$ & $(0.19)$ & $(0.01)$ & $(1.59)$ & $(0.11)$ & & & & \\
\hline & 18.00 & 2.50 & 13.00 & 4.19 & 81.36 & 12.53 & 87.47 & 63.10 & 50.42 & 294.92 \\
\hline
\end{tabular}

SIAMP-COG: Mushroom grown in the substrate with "marupá" sawdust; SIAPB-COG: with "pau de balsa" sawdust; SIAPPCOG: with grinded "pupunheira" stipe bagass; SIACN-COG: with crushed sugar cane; SIACJ-COG: with "cajuí" sawdust. Numbers in bold: average of three repetitions per analysis. Values between parentheses refer to standard deviation.

found to be low $(2.39-2.69 \%)$, as shown in Table II, and they are in agreement with several studies (Chang and Miles 1989, Sturion and Oetterer 1995, Miles and Chang 1997, Sapata 2005).

The fiber contents were found to vary with the cultivation substrate and were considered high, especially in SIACN-COG (16.17\%) and SIAMPCOG (16\%) (Table II). Andrade et al. (2008) grew L. edodes in logs of multiples species of Eucalyptus and found changes in fiber percentages ranging from 6.35 to $20.5 \%$ as a result of the influence of the wood species tested.

The ash content of the mushroom was found to vary from 4.19 to $5.72 \%$ (Table II). The highest ash content occurred in the mushroom grown in the pupunheira residue (palm tree stem), being in the range mentioned by Chang and Miles (1989) and according to, Manzi et al. (1999), Furlani (2004) and Sapata (2005). Andrade et al. (2008) obtained average percentages of ash in $L$. edodes grown in different species of Eucalyptus in the range of 2 to 5\%.

As for humidity, fresh mushroom obtained 81.36 to $84.88 \%$, values considered as normal as mushroom is made up of about $90 \%$ water (Maziero 1990). The humidity of the dried mushroom was found to range from 11.74 to 12.53 , in agreement with the results of Oliveira et al. (1999) and Shibata and Demiate (2003) for dehydrated A. blazei.

The results of total carbohydrates (with fiber fraction included) for mushrooms SIAMP-COG; SIAPB-COG; SIAPP-COG, SIACN-COG, and SIACJ-COG were $62.69,59.95,58.75,58.52$, and $63.1 \%$, respectively, and the highest results were found in the mushrooms grown in cajuí (SIACJCOG) and marupá (SIAMP-COG) residues. This was probably owing to the high amount of total fiber (13 and 16\%) present in the respective samples, which are part of the total carbohydrates, as well as owing to the lower levels in protein contained in those samples, which are lower percentages to be discounted in the total carbohydrate formula.

The available carbohydrate contents (carbohydrate from which fiber fraction is excluded) for samples SIACJ-COG and SIAMP-COG were 50.42 and $47.43 \%$, respectively (Table II). It should be mentioned that the lowest percentages in proteins present in those samples (18\%), consequently discounted in lesser percentage in the calculation of available carbohydrates, contributed to the higher value of those carbohydrates. 
The total metabolizable energy was found to be higher similar to the percentage of available carbohydrate present in the sample, which was in a larger amount in SIACJ-COG with $294.92 \mathrm{Kcal}$. The results were found to be lower than those reported by Miles and Chang (1997) for P. ostreatus.

By analyzing samples in a general way, a wide variation in the protein, lipid, ash, total available carbohydrate, and energy contents was observed in the mushroom grown in all the cultivation substrates, which was in agreement with various studies (Fasidi and Ekuere 1993, Sturion and Oetterer 1995, Wang et al. 2001, Silva et al. 2002, Furlani 2004, Sapata 2005, Das and Mukherjee 2007).

In general, it is known that the highest nutritional composition of mushrooms is related to the pileum and not the stipe; this can be proven in the studies conducted by Shibata and Demiate (2003) with $A$. blazei, and the study by Akindahunsi and Oyetayo (2006) which confirmed that in relation to protein, lipids, ash and total carbohydrates in P. tuber-regium. The results found for pileum and stipe, respectively, for protein (13.8 and 7.8\%), lipids (1.2 and $0.7 \%$ ), ash (4.9 to $2.6 \%$ ) and total carbohydrates (53.2 to $34 \%$ ) were, however, lower than the same compositions presented by $L$. strigosus grown in the different substrates used in the present research, analyzing the mushroom as a whole (Table II).

The various sources consulted indicate that there is a wide variability in the centesimal composition of mushrooms, between the same species and between different species. Such results are in agreement with the observations of Furlani (2004) and Sales-Campos et al. (2009).

\section{CONCLUSIONS}

The nutritional composition of L. strigosus varies with the cultivation substrate.

Protein levels $(18-21.5 \%)$ varied with the substrate and was considered high.
The soluble solids might have a relation with water soluble vitamins from complex B.

L. strigosus can be considered as important food owing to its nutritional features.

\section{RESUMO}

Avaliou-se a composição centesimal e análise físicoquímica do Lentinus strigosus, um cogumelo comestível de ocorrência na Amazônia brasileira, produzidos em substratos alternativos à base de resíduos madeireiros e agroindustriais. Com este objetivo, determinou-se $\mathrm{C}, \mathrm{N}$, $\mathrm{pH}$, sólidos solúveis, atividade de água, proteína, lipídios, fibra total, cinzas, carboidratos e energia. Os substratos foram formulados a partir de serragem de Simarouba amara Aubl. (marupá), Ochroma piramidale Cav. ex. Lam. (paude-balsa) e Anacardium giganteum (cajuí); e do estipe de Bactris gasipaes Kunth (pupunheira) e de Saccharum officinarum (cana-de-açúcar). Os resultados demonstraram que: a composição nutricional do L. strigosus variou com o substrato de cultivo; os valores de proteína encontrados nos cogumelos cultivados nos diferentes substratos (18 - 21,5\%) variaram de acordo com o substrato, sendo considerados elevados; os sólidos solúveis presentes nos cogumelos podem ter relação com vitaminas hidrossolúveis do complexo B; o L. strigosus pode ser considerado um importante alimento devido suas características nutricionais: alto teor de proteína, carboidratos metabolizáveis e fibras; baixos teores de lipídios e de calorias.

Palavras-chave: cogumelos comestíveis, valor nutricional, minerais, proteínas, fibras

\section{ACKNOWLEDGMENTS}

The authors are thankful to Fundação de Amparo à Pesquisa do Estado do Amazonas (FAPEAM), Coordenação de Aperfeiçoamento de Pessoal de Nível Superior (CAPES) and Conselho Nacional de Desenvolvimento Científico e Tecnológico (CNPq) for their financial support.

\section{REFERENCES}

AKINDAHUNSI A AND OYETAYO FL. 2006. Nutrient and antinutrient distribution of edible mushroom, Pleurotus tuberregium (fries) Singer. Food Sci Technol 39(5): 548-553. 
ANDRADE MCN, Minhoni MTA AND ZIED DC. 2008. Avaliação nutricional do cogumelo shiitake [Lentinula edodes (Berk.) Pegler] em função da linhagem e do tipo de eucalipto cultivado. Ciênc Tecnol Alim 28(4): 916-921.

AOAC - Association of OfFicial ANALYTICAL CHEMists. 1997. Official Methods of Analysis of A.O.A.C. International. $16^{\text {th }}$ ed., 3. rev. A.O.A.C. International. Gaithersburg, MD, 1141 p.

BRASEQ - BOLETIM TÉCNICO INFORMATIVO BRASEQ. 2005. Entendendo a atividade de água e sua importância para a qualidade de alimentos e outros produtos em geral. Disponível em: www.braseq.com.br Acesso em: 20 jul. 2005.

CARVAlho HH, Jong EV, Belló RM, SOUZA RB AND TERrA MF. 2002. Alimentos: Métodos físicos e químicos de análise. Porto Alegre: Ed. Universidade/UFRGS, p. 163-165.

Chang ST AND Miles PG. 1989. Edible mushrooms and their cultivation. Boca Raton: CRC Press Inc., 345 p.

CRISAN EV AND SANDS A. 1978. A nutritional value. In: CHANG ST AND HAYES WA (Eds), The biology and cultivation of edible mushroom. New York: Academic Press, p. 137-168.

DAS N AND MuKherJeE N. 2007. Cultivation of Pleurotus ostreatus on weed plant. Bioresource Technol 98: 27232726.

EIRA AF. 2003. Cultivo do cogumelo medicinal Agaricus blazei (Murril) ss. Heinemann ou Agaricus brasiliensis (Wasser et al.). Viçosa: Aprenda Fácil Editora, 395 p.

FASIDI IO AND EKUERE UU. 1993. Studies on Pleurotus tuber-regium (Fries) Singer: cultivation, proximate composition and mineral contents of sclerotia. Food Chem 48(3): 255-258.

FURLANI RPZ. 2004. Valor Nutricional de cogumelos cultivados no Brasil. Campinas, 88 p. Tese (Doutorado em Ciência de Alimentos), Faculdade de Engenharia de Alimentos, Universidade Estadual de Campinas (UNICAMP).

GUNDE-CIMERMAN N. 1999. Medicinal value of genus Pleurotus (Fr.) P. Karst. (Agaricales s. 1., Basidiomycetes). Intern J Med Mush 1: 60-80.

KADIRI M AND ARZAI AH. 2004. Cultivation of Lentinus subnudus Berk (Poliporales: Poliporaceae) on woodlogs. Bioresource Technol 94: 65-67.

LATINFOODS. 2002. Tabla de Composicion de Alimentos de América Latina. LATINFOODS website. Disponível em $<$ http://www.fao.org/LAmerica/grupo.htm>. Acesso em: 20 mai. 2006.

LECHNER BE AND ALBERTó E. 2007. Optimal conditions for the fruit body production of natural occurring strains of Lentinus tigrinus. Bioresource Technol 98: 1866-1869.

Malavolta E, Vitti GC AND Oliveira SA. 1989. Avaliação do Estado Nutricional das Plantas: Princípios e Aplicações. Piracicaba: Associação Brasileira para Pesquisa da Potassa e do Fosfato Piracicaba, 201 p.

Maltini E, Torregiani D, Brovetto BR AND Bertolo G. 1993. Functional properties of reduced moisture fruits as ingredients in food systems. Food Res Intern 26(6): 413-419.
Manzi P, Gambelli L, Marconi S, Vivanti V AND PizzofERRATO L. 1999. Nutrients in edible mushrooms: an inter-species comparative study. Food Chem 65(4): 477-482.

MEndonÇa ES AND Matos ES. 2005. Matéria Orgânica do Solo: Métodos de Análises. Viçosa: UFV, 107 p.

MAZIERO R. 1990. Substratos alternativos para o cultivo de Pleurotus spp. 136 p. Dissertação (Mestrado em Ciências Biológicas), Instituto de Biociências, Universidade de São Paulo (USP). (Unpublished).

Miles P AND CHANG ST. 1997. Mushroom biology: concise basics and current developments. Singapore: World Scientific, 194 p.

NEPA - NúCleo de Estudos E PesquisAs EM AlimentAÇão. 2006. Tabela de Composição de Alimentos/NEPAUNICAMP. Campinas.

OLIVEIRA ECM, OLIVEIRA ER, LIMA LCO AND VILLAS BOAS EVB. 1999. Composição centesimal do cogumelo do Sol (Agaricus blazei). R Uni Alfenas 5: 169-172.

SAlES-CAmpos C. 2008. Aproveitamento de resíduos madeireiros e da agroindústria regional para o cultivo de fungos comestíveis de ocorrência na região amazônica. 182 p. Tese (Doutorado em Biotecnologia), Universidade Federal do Amazonas (UFAM), Manaus, $182 \mathrm{p}$.

Sales-CAmpos C, Eira AF, Minhoni MTA And Andrade MCN. 2009. Mineral composition of raw material, substrate and fruiting bodies of Pleurotus ostreatus in culture. Interciencia 34 (6): 432-436.

SAPATA MRL. 2005. Valorização de resíduos agrícolas: produção de cogumelos do gênero Pleurotus. 32 p. Relatório (Final de Projeto), Instituto Nacional de Investigação Agrária e das Pescas, Estação Agronômica Nacional, Oeiras.

ShibATA CKR AND Demiate IM. 2003. Cultivo e análise da composição química de cogumelo do sol (Agaricus blazei Murril). Ci Biol Saúde 9(2): 21-32.

Silva SO, Costa SMG AND Clemente E. 2002. Chemical composition of Pleurotus pulmonarius (Fr.) Quél., substrates and residue after cultivation. Braz Arch Biol Technol 45(4): 531-535.

StURION GL AND OetTERER M. 1995. Composição química de cogumelos comestíveis (Pleurotus spp) originados de cultivo em diferentes substratos. Ciênc Tecnol Alim 15(2): 189-193.

WANG D, SAKOdA A AND SuzUKi M. 2001. Biological efficiency and nutritional value of Pleurotus ostreatus cultivated on spent beer grain. Bioresource Technol 78(3): 293-333.

YILDZ A, KARAKAPLAN M AND AYdIN F. 1998. Studies on Pleurotus ostreatus (Jacq. ex. Fr.) KUM. Var. salignus (Pers. ex. Fr.) Konr. et Maubl.: cultivation, proximate composition, organic and mineral composition of carpophores. Food Chem 61: 127-130. 